\title{
Persée
}

http://www.persee.fr

\section{Direct theory of perception : an évaluation by représentatives of indirect théories of perception}

\author{
J.P. Wagemans \\ L'année psychologique, Année 1986, Volume 86, Numéro 2 \\ p. $261-273$
}

Voir l'article en ligne

\section{Summary : Direct theory of perception}

Gibson's theory has generated a lot of discussion with indirect theories of perception. But how do representatives of these theories evaluate Gibson's ecological approach? In this article an attempt is made to provide an answer to this question. The very diverse reactions are split up into two large groups: Criticisms and reconciliation attempts. The criticisms stress the need for compulational and representational processes. Four kinds of reconciliation attempts are distinguished: (1) Changing stimulus patterns and decoding principles, (2) direct information pickup as part of a perceptual cycle, (3) not all perception is direct, and (4) direct perception as preattentive processing. Key-words : direct perception, representation, computation.

\footnotetext{
Avertissement

L'éditeur du site «PERSEE » - le Ministère de la jeunesse, de l'éducation nationale et de la recherche, Direction de l'enseignement supérieur, Sous-direction des bibliothèques et de la documentation - détient la propriété intellectuelle et les droits d'exploitation. A ce titre il est titulaire des droits d'auteur et du droit sui generis du producteur de bases de données sur ce site conformément à la loi n`98-536 du 1 er juillet 1998 relative aux bases de données.
}

Les oeuvres reproduites sur le site «PERSEE » sont protégées par les dispositions générales du Code de la propriété intellectuelle.

Droits et devoirs des utilisateurs

Pour un usage strictement privé, la simple reproduction du contenu de ce site est libre.

Pour un usage scientifique ou pédagogique, à des fins de recherches, d'enseignement ou de communication excluant toute exploitation commerciale, la reproduction et la communication au public du contenu de ce site sont autorisées, sous réserve que celles-ci servent d'illustration, ne soient pas substantielles et ne soient pas expressément limitées (plans ou photographies). La mention Le Ministère de la jeunesse, de l'éducation nationale et de la recherche, Direction de l'enseignement supérieur, Sous-direction des bibliothèques et de la documentation sur chaque reproduction tirée du site est obligatoire ainsi que le nom de la revue et- lorsqu'ils sont indiqués - le nom de l'auteur et la référence du document reproduit.

Toute autre reproduction ou communication au public, intégrale ou substantielle du contenu de ce site, par quelque procédé que ce soit, de l'éditeur original de l'oeuvre, de l'auteur et de ses ayants droit.

La reproduction et l'exploitation des photographies et des plans, y compris à des fins commerciales, doivent être autorisés par l'éditeur du site, Le Ministère de la jeunesse, de l'éducation nationale et de la recherche, Direction de l'enseignement supérieur, Sous-direction des bibliothèques et de la documentation (voir http://www.sup.adc.education.fr/bib/ ). La source et les crédits devront toujours être mentionnés. 


\title{
DIRECT THEORY OF PERCEPTION AN EVALUATION BY REPRESENTATIVES OF INDIRECT THEORIES OF PERCEPTION ${ }^{2}$
}

\author{
by Johan P. WAGEMANS ${ }^{3}$
}

RÉSUMÉ : Théorie directe de la perception : une évaluation par des psychologues représentatifs de théories indirectes.

La théorie de Gibson a engendré beaucoup de discussion autour des théories indirectes de la perception; mais comment les représentants de ces théories évaluent-ils la théorie de Gibson? Nous essayons ici de répondre $\grave{a}$ cette question. Des réactions très diverses apparaissent au sein de deux groupes d'attitudes : soit critiques, soit favorables. Les attitudes critiques spécifient qu'il est nécessaire d'introduire des processus de computation et de représentation. Les tentatives d'accords sont réparties selon quatre principes : (1) changement des principes de décodage du stimulus, (2) l'extraction de l'information comme une partie du cycle perceptif, (3) toutes les perceptions ne sont pas directes, (4) la perception directe comme processus préattentifs.

Mots clés : perception directe, représentation, calcul.

\section{INTRODUCTION}

The controversy between direct and indirect theories of perception is a hot topic in the recent literature about perception. Congresses where these matters are discussed, are numerous and important articles appear in many journals. This

1. Tiensestraat 102, B. 3000 Leuven, Belgium.

2. I am grateful to Dr. G. d'Ydewalle for a review of a previous version of this article.

3. Present address (until May 1986) : Psychologisch Laboratorium Vakgroep Psychologische Functieleer, Montessorilaan 3, Postbus 9104, 6500 HE Nijmegen. 
article concerns part of this debate, namely the evaluation of direct or ecological theory by representatives of indirect theories of perception. The reactions are very divergent and it is impossible to represent them exhaustively. An attempt is nevertheless made to group these reactions and to summarize them.

According to indirect theories, perception is the elaboration of an inadequate stimulus input. According to the direct theory of perception, on the other hand, stimulus information sufficiently specifies the environment, so that the perceiver only has to detect this information, not to elaborate it. Most authors view this opposition as the core of the contrast between direct and indirect theories of perception (e.g. Ben-Zeev, 1984; Bruce and Green, 1985; Mace, 1974; McArthur, 1982; Pick, Pick, Jones and Reed, 1982; Turvey and Shaw, 1979). The answer to the question of what is perceived, seems to have important influence on the answer to the question of how one perceives. These two questions are generally considered as central problems for every theory of perception (e.g. Mace, 1974; Marr, 1977).

In spite of the mutual entanglement of both questions, a tendency exists among indirect theorists to appreciate the ecological study of the available information, without agreeing with the theory of direct information pickup. The criticisms are therefore generally aimed at the manner in which ecological or direct theory views the perception process. Taking this into account, one tries to reconciliate the direct study of the available information with the indirect theories of information processing.

\section{Criticisms}

As stated above, representatives of indirect theories of perception criticize direct theory for their account of information detection. In summary, this theory is the following: invariants and affordances corresponding to properties of the environment have to be abstracted from the light by the perceiving organism; then, the organism resonates with or is tuned in to the environment, so that the organism's behavior is adapted to it. According to indirect theories, abstraction and resonance are not sufficient. These mechanisms of perception have to be completed with computation and representation (Fodor, 1980; Natsoulas, 1983, 1984; Ullman, 1980). 


\subsection{Computation instead of abstraction}

Direct theory is generally reproached for not giving an explanation of the mechanisms of information detection (Braddick, 1980; Haber, 1978; Hayes-Roth, 1977, 1980; Hudson, 1983; Pomerantz and Kubovy, 1981). It is stated that the ecological approach does not account for the complexity of information detection (Marr, 1982; Prazdny, 1980; Shepard, 1981, 1984; Wilding, 1983).

Gibson (1973) himself admits that the process of extraction has not been fully understood yet and his followers (e.g. Reed and Jones, 1981) also agree that further research about it is needed. It is however possible to resist the criticism that direct theory has nothing to say about information pickup. Although direct theory is still in its infancy and is not yet "perfect", ecological theorists assert that extraction of invariants in the stimulus information offers a sufficient explanation of the mechanisms of perception.

Indirect theorists on the contrary, claim that direct theory is not only suffering from growing pains, it is fundamentally deficient. According to Ullman (1980) and Haber (1983) perception is indirect, because information pickup can be analysed in different subprocesses. A demonstrable correlation between light properties and environmental characteristics is no proof of the absence of cognitive processes, according to others (BenZeev, 1981, 1984; Fodor and Pylyshyn, 1981; Wilcox and Edwards, 1982, 1983). Still, computational theory is grateful to Gibson for his studies which convincingly demonstrate the richness of stimulus information. It is not astonishing therefore that Marr (1982, p. 29) writes: "... the nearest anyone came to the level of computational theory was Gibson...". But theories as Marr's (1977, 1982) and Ullman's $(1979,1984)$ go further than Gibson: The detection of invariants is considered a complex problem of information processing dividable into different stages. What is computationally processed then, are those stimulus properties which appear to be ecologically relevant in normal circumstances. That is the reason why so many researchers (Braddick, 1980; Gregory, 1981; Hinton, 1980; Pribram, 1977; Runeson and Lind, 1981; Wilcox and Edwards, 1983; Zucker, 1980) consider Gibson as a forerunner of the computational approach (Pylyshyn, 1984). 


\subsection{Representation instead of resonance}

A second fundamental criticism against the direct approach concerns the result of the perceptual process. This is conceived as "resonance" or "tuning" and has been made clear with a radio metaphor (Gibson, 1966; Michaels and Carello, 1981; Shaw and McIntyre, 1974). Important environmental properties "broadcast" information by means of electromagnetic radiation (light) "modulated" by reflection. The peripheral sensory organs "receive the information like an "antenna" and the organism is further "tuned in" to it. What is important in this metaphor, is that information is never stored in the form of a symbolic representation. By means of the same metaphor, Weimer $(1977,1980)$ has demonstrated where the explanation fails: A radio receives the information present in the light waves, but this does mean that a radio perceives. For a radio to be able to perceive, it would be necessary to construct a perceptual experience. The information may be directly present in the order of the stimulation, the experience is not. This implies construction and inference processes on the basis of representations. Others also stress the importance of the experiential element in perception (Attneave, 1982; Ben-Zeev, 1981, 1983, 1984; Dretske, 1978; Natsoulas, 1974, 1978, 1983, 1984; Shepard, 1984). Likewise, discussions between Gibson (1969) and Yolton (1968) and between Gibson $(1972,1973)$ and Gyr (1972 $a$ and $b$ ) can be reduced to this topic. Even the criticisms of Hamlyn (1977) and Heil $(1979,1981)$ handle this problem. Fodor and Pylyshyn (1981) explain the problem by means of an example. If you watch the Pole Star, you see a big round ball of burning gasses. This perception depends only upon the stimulus information specifying this star. But to see the Pole Star as Pole Star, implies an influence from knowledge. The difference between to see and to see as may seem trivial, but it is not. For it concerns the fundamental link between perception and behavior. Somebody who is lost in the middle of a foggy night, has to know that he is seeing the Pole Star to be able to orient himself by means of this star. The seeing of just one or another burning ball is insufficient as a point of orientation. One has to see or recognize the star as the Pole Star, to base one's behavior on that perception. The cognitive consequences of perception are thus not only dependent on whether the world is seen or not, 
but also on how the world is seen or represented. To explain this difference, indirect theories are based on the notion of mental representation. Direct theory explains the perceiving of $\mathrm{X}$ as the detecting of the corresponding invariants $\mathrm{X}^{\prime}$ in the available light. But what happens if some people see $\mathrm{X}$ as an animal, others as a dog, a German shepherd or the neighbour's dog Sam? Are these perceptual experiences caused by different properties in the light? To answer this question positively, would lead to an endless proliferation of stimulus properties (de Wit and de Swart, 1983; Hudson, 1983). To avoid this, indirect theories of perception have made an appeal to mental representations, which can be more or less detailed, depending on the available knowledge.

In summary, indirect theories consider computational and representational processes necessary to give adequate explanations of information pickup and perceptual experience. Taking into account these criticisms of the ecological notions of abstraction and resonance, a number of reconciliation attempts are proposed.

\section{Reconciliation attempts}

When good as well as bad elements are found in the same theory, an attempt to improve the theory can be made by maintaining the better parts and complementing it with good aspects of another theory. This may be done in the case of Gibson's direct theory of perception. One may try to integrate parts of ecological and constructivistic theories in a meaningful manner. Various attempts have been made to do just that. These different attempts have been divided into four groups.

\subsection{Changing stimulus patterns and decoding principles}

A first way to supplement Gibson's ecological approach, comes from meeting the above mentioned criticism about information abstraction. Many theorists agree in stressing the richness of stimulus information, in changing stimulus patterns in particular, but consider the extraction of invariants from the flow of information as a complex process of information processing. Johansson (e.g. 1970) has always explicitly stressed Gibson's merits and the accordances between their experimental work. But he has refuted the thesis of direct perception theory whereby 
a moving organism receives specific information about the environment through the changing stimulus patterns and therefore needs no further information processing. According to him and many others, it is necessary to appeal to decoding principles which automatically split up the complex changing patterns in their constituent parts (Epstein, 1977, 1980; Johansson, von Hofsten and Jansson, 1980; Ullman, 1979; Wilcox and Edwards, 1982). Johansson (1970) himself has stressed the fact that this analysis of movement takes place automatically and inevitably and thus never leads to a dangerous subjectivity of the organism. $\mathrm{He}$ has explicitly viewed his line of work as a compromise between two extremes: "... It is our opinion that our research program will help us to avoid a not uncommon appeal to subjectivity in the basic functions of the visual apparatus, but at the same time to avoid following the pendulum swing to the other extreme: An unstructured belief in stimulus information..." (Johansson, 1970, p. 74). In reply to this, Gibson (1970) has called the contrast between the contributions of perceiver and external stimulation a false one. From the ecological point of view, this reconciliation attempt is thus disposed of as a "muddle of thought".

\subsection{Direct information pickup as part of a perceptual cycle}

Taking into account the criticisms of a direct theory of resonance, another reconciliation attempt between ecological and constructivistic theories is possible. Somewhere in a theory of perception, a place must be given to the perceptual experience. Neisser $(1976,1977,1978)$ does this in his theory of the perceptual cycle. The information about the environmental object is present in the light and is picked up directly. This changes the existing cognitive schemata of the perceiving organism. These mental representations in turn indicate the right direction for further environmental exploration and further scanning of the available information. The need for an explanation of the non-randomness of this exploration process is also stressed by others (BenZeev, 1981; Hayes-Roth, 1980; Norman, 1979; Weckowitz, 1972). Neisser $(1976$, p. XII) himself says that the notion of schemata is at the core of his "...attempt to reconcile the concepts of information processing and information pickup, both of which capture too much of truth to be ignored...". Other reconciliation attempts can be submitted under the same heading (Ben-Zeev, 
1983, 1984; Hirst, 1978; Pribram, 1977; Shepard, 1984; Weimer, 1974 a). All consider perception as a constructive process, based on abstract information which is picked up directly.

\subsection{Not all perception is direct}

Some critics admit that direct perception is possible under optimal circumstances, because elaboration processes are superfluous when sufficient stimulus information is available (Hochberg, 1981; Pomerantz and Kubovy, 1981; Shepard, 1984). This would not differ much from Gibson's position, except for the fact that these people immediately add that such situations rarely occur. Mostly, information in the ambient optic array is not sufficient to specify the objects and events in the environment. Here direct and indirect are considered as two ends of the same continuum: The difference is a matter of degree, dependent on the interaction of task difficulty and stimulus richness (Baron, 1980; Clark, 1978; McArthur, 1982; Norman, 1983; Ullman, 1980). Gibson (e.g. 1970) also inclines to this position, but his ecological followers radically refuse to take such a stance.

\subsection{Direct perception as preattentive processing}

This reconciliation attempt is not fully independent of the previous one. Here, construction is considered the normal case, because a conscious, explicit perception implies the construction of an internal representation. Gibson's direct perception on the other hand, is viewed as an exceptional form of unconscious, tacit information pickup (Aurell, 1984; Bridgeman, 1980; Halwes, 1974; Koenderink, 1980; Turvey, 1974; Weimer, 1974 b). This form of information detection is compared with what Neisser (1967) has called preattentive processing (Halwes, 1974; Koenderink, 1980; Weimer, $1974 b, 1980$ ). Some people for example can pickup a given name from the newspaper with remarkably high speed and accuracy. For doing this, one has to learn to experience the visual information without constructing the experience. One has to learn to scan the visual field, just to look without knowing what one is seeing. Only when detecting the needed word or object, one has to construct a representation so that one is aware of it. By means of preattentive processing, tacit knowledge is reached, knowledge that is possessed without knowing that it is possessed (Polanyi, 1964, 1966). This possibility has been taken into account by Gibson $(1976,1978)$ as is 
apparent from the following citation: “...We will perceive directly and immediately their affordances for us. The meanings will be tacit of course, not explicit..." (Gibson, 1976, p. 415). But Gibsonians after him, though enthusiastic about it at first (e.g. Turvey, 1974), later rejected this reconciliation attempt.

\section{Conclusion}

It is astonishing how much trouble is taken by representatives of indirect theories of perception to integrate the merits of direct theory in the cognitive framework. Equally striking is the vehemence with which representatives of the direct or ecological approach want to get rid of these reconciliation attempts. Gibson and his ecological followers stress the revolutionary character of their approach and point out the intrinsic incompatibility between direct and indirect theories of perception (Cutting, 1982). This is an essential feature of what Kuhn (1970) has called revolutionary periods in science. Therefore, Gibson's direct theory of perception can be considered as a "paradigmatic revolution" against the cognitive approach as "normal science". This thesis has been defended elsewhere (Wagemans, manuscript in preparation), and has some important consequences. It implies that the struggle between the two approaches can never be decided by one single, so called "critical" experiment. Still, relevant experimental research is wanted and has been done recently, but it can only be considered as a contribution to a possible solution in the long run (Aurell, 1984; Norman, 1983; Wagemans and d'Ydewalle, manuscript in preparation). Meanwhile, it can be interesting to continue the debate on a theoretical or metatheoretical level. Here, part of this debate has been summarized and synthesized to make up a temporary balance.

\section{SUMMARY : Direct theory of perception}

Gibson's theory has generated a lot of discussion with indirect theories of perception. But how do representatives of these theories evaluate Gibson's ecological approach? In this article an attempt is made to provide an answer to this question. The very diverse reactions are split up into two large groups: Criticisms and reconciliation attempts. The criticisms stress the need for computational and representational processes. Four kinds of 
Gibson (J. J.) - A theory of direct visual perception, in J. R. Royce et W. W. Rozeboom (Edit.), The psychology of knowing, New York, Gordon \& Breach, 1972, 215-227.

Gibson (J. J.) - Direct visual perception: a reply to Gyr, Psychological Bulletin, 1973, 79, 396-397.

Gibson (J. J.) - The theory of affordances and the design of the environment (Written in 1976) in E. S. Reed et R. K. Jones (Edit.), Reasons for realism, Hillsdale (NJ), Erlbaum, 1982, 413-416.

Gibson (J. J.) - A note on what exists at the ecological level of reality (Written in 1978) in E. S. Reed et R. K. Jones (Edit.), Reasons for realism, Hillsdale (NJ), Erlbaum, 1982, 416-418.

Gregory (R. L.) - Links of brain, in R. L. Gregory, Mind in science: a history of explanations in psychology and physics, Londres, Weidenfeld \& Nicolson, 1981, 359-415.

Gyr (J. W.) - Is a theory of direct visual perception adequate? Psychological Bulletin, $1972 a, 77,246-261$.

Gyr (J. W.) - Comments on Gibson's paper, in J. R. Royce et W. W. Rozeboom (Edit.), The psychology of knowing, New York, Gordon \& Breach, $1972 b, 231-232$.

Haber (R. N.) - Visual perception, Annual Review of Psychology, 1978, $29,31-59$.

Haber (R. N.) - Psychology cannot blame its theoretical mistakes on physics, Acta Psychologica, 1983, 53, 155-162.

Halwes (T.) - Structural realism, coalitions, and the relationship of Gibsonian, constructivist, and Buddhist theories of perception, in W. B. Weimer et D. S. Palermo (Edit.), Cognition and the symbolic processes, Vol. 1, Hillsdale (NJ), Erlbaum, 1974, 367-383.

Hamlyn (D. W.) - The concept of information in Gibson's theory of perception, Journal for the Theory of Social Behaviour, 1977, 7, 5-16.

Hayes-Roth (F.) - Critique of Turvey's "Contrasting orientations to the theory of visual information processing", Psychological Review, 1977, $84,531-535$.

Hayes-Roth (R.) - Mediating the so-called immediate processes of perception, Behavioral and Brain Sciences, 1980, 3, 386-387.

Heft (H.) - What Heil is missing in Gibson: a reply, Journal for the Theory of Social Behaviour, 1980, 10, 187-193.

Heil (J.) - What Gibson is missing, Journal for the Theory of Social Behaviour, $1979,9,265-269$.

Heil (J.) - Gibsonian sins of omission, Journal for the Theory of Social Behaviour, 1981, 11, 307-311.

Hinton (G. E.) - Inferring the meaning of direct perception, Behavioral and Brain Sciences, 1980, 3, 387-388.

Hirst (R. J.) - Science and anti-science in the philosophy of perception, in P. K. Machamer et R. G. Turnbull (Edit.), Studies in perception: interrelations in the history of philosophy and science, Ohio, State University Press, 1978, 377-401.

Hochberg (J.) - Levels of perceptual organization, in L. Kubovy et J. R. Pomerantz (Edit.), Perceptual organisation, Hillsdale (NJ), Erlbaum, 1981, 255-278.

Hudson (P. T. W.) - A rose is a rose: minimalism in perception, Acta Psychologica, 1983, 53, 163-169.

Johansson (G.) - On theories for visual space perception: a letter to Gibson, Scandinavian Journal of Psychology, 1970, 11, 67-74.

Johansson (G.), von Hofsten (G.), Jansson (G.) - Direct perception and perceptual processes, Behavioral and Brain Sciences, 1980, 3, 388-389. 
Koenderink (J. J.) - Why argue about direct perception? Behavioral and Brain Sciences, 1980, 3, 390-391.

Kuhn (T. S.) - The structure of scientific revolutions, $2^{\mathrm{e}}$ éd., Chicago, University of Chicago Press, 1970.

Mace (W. M.) - Ecologically stimulating cognitive psychology : Gibsonian perspectives, in W. B. Weimer et D. S. Palermo (Edit.), Cognition and the symbolic processes, Vol. 1, Hillsdale (NJ), Erlbaum, 1974, 137-164.

Marr (D.) - Artificial intelligence: a personal view, Artificial Intelligence, 1977, 9, 37-48.

Marr (D.) - Vision: a computational investigation into the human representation and processing of visual information, San Francisco, Freeman, 1982.

McArthur (D. J.) - Computer vision and perceptual psychology, Psychological Bulletin, 1982, 92, 283-309.

Michaels (C. F.), Carello (C.) - Direct perception, Englewood Cliffs (NJ), Prentice-Hall, 1981.

Natsoulas (T.) - The subjective, experiential element in perception, Psychological Bulletin, 1974, 81, 611-631.

Natsoulas (T.) — Residual subjectivity, American Psychologist, 1978, 33, 269-283.

Natsoulas (T.) - What are the objects of perceptual consciousness? American Journal of Psychology, 1983, 96, 435-467.

Natsoulas (T.) - Towards the improvement of Gibsonian perception theory, Journal for the Theory of Social Behaviour, 1984, 18, 231-258.

Neisser (U.) - Cognitive psychology, New York, Appleton Century Crofts, 1967.

Neisser (U.) - Cognition and reality, San Francisco, Freeman, 1976.

Neisser (U.) - Gibson's ecological optics: the consequences of a different stimulus description, Journal for the Theory of Social Behaviour, 1977, 7, 17-28.

Neisser (U.) - Anticipations, images, and introspection, Cognition, 1978, $6,169-174$.

Norman (D. A.) - Perception, memory, and mental processes, in L. G. Nilsson (Edit.), Perspectives on memory research: essays in honor of Uppsala University's 500th anniversary, Hillsdale (NJ), Erlbaum, 1979, 121-144.

Norman (J.) - Are the direct and indirect theories of perception incompatible? Behavioral and Brain Sciences, 1983, 6, 729-731.

Pick (A. D.), Pick (H. L., Jr.), Jones (R. K.), Reed (E. S.) - James Jerome Gibson: 1904-1979, American Journal of Psychology, 1982, 95, 693-700.

Polanyi (M.) - Personal knowledge: towards a post-critical philosophy, New York, Harper, 1964.

Polanyi (M.) - The tacit dimension, New York, Garden City, Doubleday, 1966.

Pomerantz (J. R.), Kubovy (M.) - Perceptual organization: an overview, in M. Kubovy et J. R. Pomerantz (Edit.), Perceptual organization, Hillsdale (NJ), Erlbaum, 1981, 423-456.

Prazdny (K.) - How wrong is Gibson? Behavioral and Brain Sciences, 1980, 3, 394-395.

Pribram (K. H.) - Some comments on the nature of the perceived universe, in R. E. Shaw et J. D. Bransford (Edit.), Perceiving, acting, and knowing: toward an ecological psychology, Hillsdale (NJ), Erlbaum, 1977, 83-101.

Pylyshyn (Z. W.) - Computation and cognition: toward a foundation for cognitive science, Cambridge (MA), MIт Press, 1984.

Reed (E. S.), Jones (R. K.) - Is perception blind? Journal for the Theory of Social Behaviour, 1981, 11, 87-91. 
Runeson (S.) - There is more to psychological meaningfulness than computation and representation, Behavioral and Brain Sciences, 1980, 3, $399-400$.

Runeson (S.), Lind (M.) - S. Ullman's "The interpretation of visual motion": a critical review, Journal of Mathematical Psychology, 1981, 23, 273-284.

Shaw (R. E.), Bransford (J. D.) - Introduction: psychological approaches to the problem of knowledge, in R. E. Shaw et J. D. Bransford (Edit.), Perceiving, acting, and knowing: toward an ecological psychology, Hillsdale (NJ), Erlbaum, 1977, 1-39.

Shaw (R. E.), McIntyre (M.) - Algoristic foundations to cognitive psychology, in W. B. Weimer et D. S. Palermo (Edit.), Cognition and the symbolic processes, Vol. 1, Hillsdale (NJ), Erlbaum, 1974, 305-362.

Shaw (R. E.), Pittenger (J. B.) - Perceiving the face of change in changing faces: implications for a theory of object perception, in R. E. Shaw et J. D. Bransford (Edit.), Perceiving, acting, and knowing: toward an ecological psychology, Hillsdale (NJ), Erlbaum, 1977, 103-132.

Shepard (R. N.) - Psychophysical complementarity, in M. Kubovy, J. R. Pomerantz (Edit.), Perceptual organization, Hillsdale (NJ), Erlbaum, 1981, 279-341.

Shepard (R. N.) - Ecological constraints on internal representation: resonant kinematics of perceiving, imagining, thinking, and dreaming, Psychological Review, 1984, 91, 417-447.

Turvey (M. T.) - Constructive theory, perceptual systems, and tacit knowledge, in W. B. Weimer et D. S. Palermo (Edit.), Cognition and the symbolic processes, Vol. 1, Hillsdale (NJ), Erlbaum, 1974, 165-180.

Turvey (M. T.), Prindle (S. S.) - Modes of perceiving: abstracts, comments, and notes, in H. L. Jr. Pick et E. Saltzman (Edit.), Modes of perceiving and processing information, Hillsdale (NJ), Erlbaum, 1978, 205-224.

Turvey (M. T.), Shaw (R. E.) - The primacy of perceiving: an ecological reformulation of perception for understanding memory, in L. G. Nilsson (Edit.), Perspectives on memory research: essays in honor of Uppsala University's 500th anniversary, Hillsdale (NJ), Erlbaum, 1979, 167-222.

Ullman (S.) - The interpretation of visual motion, Cambridge (MA), мIт Press, 1979.

Ullman (S.) - Against direct perception, Behavioral and Brain Sciences, $1980,3,373-381$.

Ullman (S.) - Visual routines, Cognition, 1984, 18, 97-149.

Wagemans (J. P.) - Gibson's direct theory of perception as a "paradigmatic revolution" against cognitive psychology as "normal science" (en préparation).

Wagemans (J. P.), D'Ydewalle (G.) - Direct versus indirect tunnel effect: an experimental contribution to the theoretical debate between direct and indirect theories of perception (en préparation).

Weckowitz (T. E.) - A discussion of Gibson's paper, in J. R. Royce et W. W. Rozeboom (Edit.), The psychology of knowing, New York, Gordon \& Breach, 1972, 228-230.

Weimer (W. B.) - The problem of perception and the reconciliation of Gibsonian and structural realism, in W. B. Weimer et D. S. Palermo (Edit.), Cognition and the symbolic processes, Vol. 1, Hillsdale (NJ), Erlbaum, $1974 a, 425-427$.

Weimer (W. B.) - The problem of tacit knowledge: will your real head stand up and tell us about meaning, in W. B. Weimer et D. S. Palermo (Edit.), Cognition and the symbolic processes, Vol. 1, Hillsdale (NJ), Erlbaum, $1974 b, 427-430$. 
Weimer (W. B.) - A conceptual framework for cognitive psychology: motor theories of the mind, in R. E. Shaw et J. D. Bransford (Edit.), Perceiving, acting, and knowing: toward an ecological psychology, Hillsdale (NJ), Erlbaum, 1977, 267-311.

Weimer (W. B.) - Logical atomism and computation do not refute Gibson, Behavioral and Brain Sciences, 1980, 3, 405.

Wilcox (S.), Edwards (D. A.) - Some Gibsonian perspectives on the ways that psychologists use physics, Acta Psychologica, 1982, 52, 147-163.

Wilcox (S.), Edwards (D. A.) - Psychology and physics: a reply to our critics, Acta Psychologica, 1983, 53, 177-182.

Wilding (J. M.) - Perception: from sense to object, New York, St. Martin's Press, 1983.

Yolton (J.) - On Gibson's realism, Synthese, 1969, 19, 400-406.

Zucker (S. W.) - The computational/representational paradigm as normal science: further support, Behavioral and Brain Sciences, 1980, 3, 406-407.

(Acceptẻ le 23 janvier 1986.) 